\title{
Constitutional Interpretation, Intelligent Fidelity, and (im)Perfection: on James E. Fleming's Fidelity to our Imperfect Constitution*
}

\section{Interpretación constitucional, fidelidad inteligente e (im)perfección: sobre la fidelidad a nuestra Constitución imperfecta de James E. Fleming}

\author{
Imer B. FLORES ${ }^{* *}$
}

\section{Resumen:}

En este artículo, evalúo el libro Fidelity to Our Imperfect Constitution. For Moral Readings and Against Originalisms de James E. Fleming. Para tal propósito: en la parte II revalúo la "lectura moral" de Ronald Dworkin; en la parte III, reexamino el argumento de Fleming tanto "a favor de las lecturas morales y en contra de los originalismos", el cual puede ser caracterizado como "fidelidad a nuestra constitución imperfecta"; en la parte IV, explicito tres útiles dicotomías para distinguir entre lecturas morales, originalismos y pragmatismos jurídicos: (1) fidelidad y antifidelidad; (2) interpretación y no interpretación aka (re)construcción, (re)invención y legislación (judicial), y (3) perfección-imperfección. Adicionalmente, reintroduzco la distinción de Lon L. Fuller entre "fidelidad inteligente e ininteligente", para apuntar la clase de fidelidad que los lectores morales y todos los demás deben adoptar: una fidelidad inteligente; y, finalmente, presento mi conclusión general.

\section{Palabras clave:}

Interpretación constitucional, fidelidad al derecho, fidelidad inteligente, interpretivismo, lectura moral, originalismo, perfeccionismo, pragmatismo jurídico, constitucionalismo vivo, Ronald Dworkin, James E. Fleming, Lon L. Fuller.

* Artículo recibido el 12 de mayo de 2016 y aceptado para su publicación el 11 de octubre de 2016.

A previous version was published in a "Book Symposium" on James E. Fleming's Fidelity to Our Imperfect Constitution as "Intelligent or Unintelligent Fidelity?" (2016) 31 Constitutional Commentary 397.

** Professor-Researcher, Institute for Legal Research (IIJ) and Law School (FD) of the National Autonomous University of Mexico (UNAM). 
Esta revista forma parte del acervo de la Biblioteca Jurídica Virtual del Instituto de Investigaciones Jurídicas de la UNAM

IMER B. FLORES

\section{Abstract:}

In this Article, I assess James E. Fleming's Fidelity to Our Imperfect Constitution. For Moral Readings and Against Originalisms. For that purpose: in Part II, I reexamine Ronald Dworkin's "moral reading"; in Part III, I reevaluate Fleming's argument both "for moral readings and against originalisms", which can be characterized as "fidelity to our imperfect constitution"; in part IV, I explicit three very helpful dichotomies to distinguish between moral readings, originalisms and legal pragmatism aka living constitutionalism: (1) fidelity and anti-fidelity; (2) interpretation and non-interpretation aka (re)construction, (re)invention and (judicial) legislation; and (3) perfectionimperfection. Additionally, I reintroduce Lon L. Fuller's distinction between "intelligent and unintelligent fidelity", to point out the kind of fidelity that moral readers and everyone else must adopt: an intelligent fidelity; and, finally, I present my general conclusion.

\section{Keywords:}

Constitutional interpretation, fidelity to the law, intelligent fidelity, interpretivism, moral reading, originalism, legal pragmatism, living constitutionalism, perfectionism, Ronald Dworkin, James E. Fleming, Lon L. Fuller.

The moral reading insists that they [i.e. the drafters and the ratifiers] misunderstood the moral principle that they themselves enacted into law. The originalist strategy would translate that mistake into enduring constitutional law.

Ronald Dworkin, Freedom's Law (1996).

We have to choose between an abstract, principled, moral reading... and a concrete, dated, reading.

Ronald Dworkin, "The Arduous Virtue of Fidelity" (1997). 
Esta revista forma parte del acervo de la Biblioteca Jurídica Virtual del Instituto de Investigaciones Jurídicas de la UNAM

CONSTITUTIONAL INTERPRETATION, INTELLIGENT FIDELITY, AND (IM) PERFECTION:...

SummaRY: I. Introduction. II. Ronald Dworkin's moral reading. III. Fleming's fidelity to our imperfect Constitution: moral readings v. originalisms (and living constitutionalisms). IV. Constitutional fidelity, interpretation, and imperfection: intelligent or unintelligent? V. Conclusion. VI. Bibliography.

\section{INTRODUCTION}

Advocating a moral reading to interpretation, in general, and to constitutional interpretation, in particular, I cannot do anything less - as a fellow moral reader - than celebrate the appearance of James E. Fleming's Fidelity to Our Imperfect Constitution. For Moral Readings and Against Originalisms. ${ }^{1}$ I endorse completely the commendations included on its dust jacket, especially, where, on the one hand, Richard Fallon salutes: "James Fleming emerges in this book as the ablest current defender of a 'moral reading' approach (long championed by Ronald Dworkin) that calls upon judges to make candid moral judgments in interpreting the Constitution we have, not fashioning a new one". And, on the other hand, Michael C. Dorf states: "Fleming picks up the torch laid down by the late great Ronald Dworkin as the leading champion of a moral reading of the Constitution. He is a worthy successor".

In the "Acknowledgments" section of the book, the author declares explicitly that it is a "sequel or companion"2 to one co-authored with Sotirios A. Barber on and entitled Constitutional Interpretation, ${ }^{3}$ but remains implicit that it is also a "sequel or companion" to another one co-authored with Linda C. McClain on constitutional liberalism (as a form of mild perfectionism) and titled Ordered Liberty, ${ }^{4}$ as well

1 James E. Fleming, Fidelity to Our Imperfect Constitution. For Moral Readings and Against Originalisms (Oxford University Press 2015).

2 Id. at xi.

3 Sotirios A. Barber \& James E. Fleming, Constitutional Interpretation. The Basic Questions (Oxford University Press 2007).

4 James E. Fleming \& Linda C. McClain, Ordered Liberty. Rights, Responsibilities, and Virtues (Harvard University Press 2013). 
Esta revista forma parte del acervo de la Biblioteca Jurídica Virtual del Instituto de Investigaciones Jurídicas de la UNAM

as to his own Securing Constitutional Democracy. ${ }^{5}$ Additionally, he discloses that "Fidelity to Our Imperfect Constitution", ${ }^{6}$ a homonymous article: "is the inspiration not only for the name of this book but also for my longstanding conviction that it is imperative to challenge the originalists pretensions to a monopoly on concern for fidelity in constitutional interpretation". ${ }^{7}$

This article was Fleming's contribution to a Symposium that he co-organized on "Fidelity in Constitutional Theory". The Symposium and his response were prompted by the publication of Ronald Dworkin's Freedom's Law. The Moral Reading of the American Constitution, ${ }^{8}$ and his 1996 Robert L. Levine Distinguished Lecture at Fordham University Law School, entitled "The Moral Reading of the Constitution", which was published the following year as "The Arduous Virtue of Fidelity: Originalism, Scalia, Tribe, and Nerve". 9

In this Article, I review James E. Fleming's Fidelity to Our Imperfect Constitution. For Moral Readings and Against Originalisms. For that purpose: in Part II, I reexamine Dworkin's "moral reading"; in Part III, I reevaluate Fleming's argument both "for moral readings and against originalisms", which can be characterized as "fidelity to our imperfect constitution"; and, finally, in part IV, I explicit my conclusions, including the kind of fidelity that moral readers and everyone else must adopt: an intelligent fidelity.

\section{RONALD DWORKIN'S MORAL READING}

Dworkin's "moral reading" has been traced all the way back to the publication of Taking Rights Seriously, where he accentuated -in

5 James E. Fleming, Securing Constitutional Democracy. The Case of Autonomy (The University of Chicago Press 2006).

${ }^{6}$ James E. Fleming, 'Fidelity to Our Imperfect Constitution' (1997) 65 Fordham L. Rev. 1335.

7 Fleming (n 1) xiii.

8 Ronald Dworkin, Freedom's Law. The Moral Reading of the American Constitution (Harvard University Press 1996).

9 Ronald Dworkin, 'The Arduous Virtue of Fidelity: Originalism, Scalia, Tribe, and Nerve' (1997) 65 Fordham L. Rev. 1249. 
Esta revista forma parte del acervo de la Biblioteca Jurídica Virtual del Instituto de Investigaciones Jurídicas de la UNAM

Chapter 5 "Constitutional Cases" - his concern with the "philosophy of constitutional adjudication" and argued that "[c]onstitutional law can make no genuine advance until it isolates the problem of rights against the state and makes that problem part of its own agenda. That argues for a fusion of constitutional law and moral theory". ${ }^{10}$ However, the origin of this multi-cited passage is earlier, since it appeared, for the first time, in the New York Review of Books, as "A Special Supplement: The Jurisprudence of Richard Nixon", which ends with a final paragraph (not included in the book version) commenting on the then recent appointment of William H. Rehnquist as Associate Justice to the Supreme Court (1972-1986) and anticipating somehow that he will be later on nominated by Ronald Reagan to become the $16^{\text {th }}$ Chief Justice of the Supreme Court (1986-2005): ${ }^{11}$

Mr. Justice Rehnquist is relatively young, and he has demonstrated intellectual power; it is likely that he will become the intellectual leader of the Nixon Court. Contrary to Nixon's advertisement, he is not, on the record, a champion of judicial restraint. He is a conservative activist, who can be expected forcefully to argue not for deference but for a narrow conception of individual rights. Liberals who oppose that conception will need more than the old rhetoric about the Court being the moral tutor to the nation; they will need a moral theory that shows why the rights they insist on are requirements of human dignity, or are for some other reason requirements that the nation must recognize to make good the promise of its constitutional system.

In a few words, a moral reading is necessary to "make good" the promise(s) of a Constitution. Constitutions are drafted - here, there and everywhere - in abstract normative terms, stating not only where we are in the present and even where we were in the past,

10 Ronald Dworkin, Taking Rights Seriously (Harvard University Press 1977; $2^{\text {nd }}$ ed. "With a Reply to Critics", 1978) 131, 149. See Ronald Dworkin, Law's Empire (Harvard University Press 1986) 90: "Jurisprudence is the general part of adjudication, silent prologue to any decision at law". See also Dworkin (n 8) 2: "The moral reading therefore brings political morality into the heart of constitutional law".

11 Ronald Dworkin, 'A Special Supplement: The Jurisprudence of Richard Nixon' (1972), N. Y. Rev. Books (May 4) <http://www.nybooks.com/articles/1972/05/04/aspecial-supplement-the-jurisprudence-of-richard-/> accesed 16 september 2016. 
Esta revista forma parte del acervo de la Biblioteca Jurídica Virtual del Instituto de Investigaciones Jurídicas de la UNAM

but also where we expect to be in the future. A moral reading of the Constitution as written based on the interpretation and application of abstract clauses containing principles, including moral ones, is necessary and constitutions should not be rewritten via the mutation of the old document or the invention of a new one. In Dworkin's words: "The moral reading proposes that we all — judges, lawyers, citizens - interpret and apply these abstract clauses on the understanding that they invoke moral principles about political decency and justice". ${ }^{12}$ Furthermore, as he insisted: ${ }^{13}$

Judges may not read their own convictions into the Constitution. They may not read the abstract moral clauses as expressing any particular moral judgment, no matter how much that judgment appeals to them, unless they find it consistent in principle with the structural design of the Constitution as a whole, and also with the dominant lines of past constitutional interpretation by other judges. They must regard themselves as partners with other officials, past and future, who together elaborate a coherent constitutional morality, and they must take care to see that what they contribute fits with the rest. (I have elsewhere said that judges are like authors jointly creating a chain novel in which each writes a chapter that makes sense as part of the story as a whole).

In that sense, Dworkin not only assumes the distinction between interpretation and invention, but also applies the dimensions of "fit" and "justification" to distinguish them, ${ }^{14}$ whatever fits and is justified counts as interpretation, and whatever does not as invention:

12 Dworkin (n 8) 2.

13 Ibid 10. See Ronald Dworkin, A Matter of Principle (Harvard University Press 1985) 158-162. See also Dworkin, Law's Empire (n 10) 228-238.

14 See Dworkin, Law's Empire (n 10) 239: “The judge's decision... must be drawn from an interpretation that both fits and justifies what has gone before, so far as that is possible"; and Dworkin, A Matter of Principle (n 13) 143 (where he argued "there are two dimensions along which it must be judged whether a theory provides the best justification of available legal materials: the dimension of fit and the dimension of political morality"). See also James E. Fleming, 'Fit, Justification, and Fidelity in Constitutional Interpretation' (2013) 93 Boston U. L. Rev. 1283 (reprinted in a slightly different form in (2015) 9 Problema. Anuario de Filosofía y Teoría del Derecho 53). 
Esta revista forma parte del acervo de la Biblioteca Jurídica Virtual del Instituto de Investigaciones Jurídicas de la UNAM

CONSTITUTIONAL INTERPRETATION, INTELLIGENT FIDELITY, AND (IM) PERFECTION:...

"The justification need not fit every aspect or feature of the standing practice, but it must fit enough for the interpreter to be able to see himself as interpreting that practice, not inventing a new one". ${ }^{15}$

The distinction between interpretation and invention is helpful to distinguish Dworkin from some liberals, who have called the Constitution a "living" document and have said that it must be "brought up to date" to match new circumstances and sensibilities. By taking an "active" approach and by accepting John Hart Ely's characterization of their position as a "noninterpretive", they seem to suggest change and reform, i. e. "inventing a new document rather than interpreting the old one". ${ }^{16}$

Although the distinction is enough to insulate Dworkin from the "living constitutionalists", he introduces a further qualification in the kind of interpretation that he has in mind to isolate himself from the so-called "originalists", who insist on rejecting the notion of a "living constitution" 17 by making "the contemporary Constitution too much the dead hand of the past". ${ }^{18}$ Succinctly, interpretation

15 Dworkin, Law's Empire (n 10) 66. See Ronald Dworkin, Justice in Robes (Harvard University Press 2006) 15: "Any lawyer has built up, through education, training, and experience, his own sense of when an interpretation fits well enough to count as an interpretation rather than an invention". See also Imer B. Flores, 'The Legacy of Ronald Dworkin (1931-2013): A Legal Theory and Methodology for Hedgehogs, Hercules, and One Right Answers' (2015) 9 Problema. Anuario de Filosofía y Teoría del Derecho 157, 174-176 (accentuating the interpretive not inventive nature of Dworkin's model).

16 Dworkin (n 8) 4. See John Hart Ely, Democracy and Distrust. A Theory of Judicial Review (Harvard University Press 1980). See also Charles A. Beard, "The Living Constitution' (1936) 185 Annals of the American Association of Political Sciences 29; Bruce Ackerman, 'The Living Constitution' (2007) 120 Harv. L. Rev. 1737; and David A. Strauss, The Living Constitution (Oxford University Press 2010).

17 See Robert H. Bork, 'Neutral Principles and some First Amendment Problems' (1971) 47 Indiana L. J. 1; William H. Rehnquist, 'The Notion of a Living Constitution' (1976) 54 Texas L. Rev. 693, reprinted in (2005-2006) 29 Harv. J. L. \& Pub. Pol'y 395; Raoul Berger, Government by the Judiciary. The Transformation of the Fourteenth Amendment (Harvard University Press 1977); Antonin Scalia 'Originalism: The Lesser Evil' (1989) 57 U. Cin. L. Rev. 849; and Robert H. Bork, The Tempting of America. The Political Seduction of the Law (The Free Press 1990).

18 Dworkin (n 8) 14. See Antonin Scalia, quoted in Fleming (n 1) vii: "[The Constitution is] not a living document. It's dead, dead, dead". 
Esta revista forma parte del acervo de la Biblioteca Jurídica Virtual del Instituto de Investigaciones Jurídicas de la UNAM

has to be a "creative" judicial activity - an exercise of "constructive interpretation" - that is "interpretive", not "inventive", "legislative", and as such a form of "judicial invention or legislation". ${ }^{19}$ In Dworkin's words: "[C]onstructive interpretation is a matter of imposing purpose on an object or practice in order to make of it the best possible example of the form or genre to which it is taken to belong". ${ }^{20}$ It is worth noting that legal interpretation, including constitutional interpretation, is by definition creative and even constructive, $i$. $e$. giving meaning and sense to a justifying principle of a rule. ${ }^{21}$

Not surprisingly, some originalists resist the idea of a "constructive interpretation", and have tried to maintain a sharp distinction between (constitutional) interpretation and (constitutional) construction. According to the distinction, whatever is (constitutional) interpretation cannot be (constitutional) construction, and vice ver$s a .{ }^{22}$ Hence, this argument not only claims that what Courts do or

19 See Southern Pacific v. Jensen, 244 U.S. 205, 221-222 (1917) (Holmes, J. dissenting): "I recognize without hesitation that judges do and must legislate, but they can do so only interstitially; they are confined from 'molar to molecular motions'”; and H. L. A. Hart, The Concept of Law (Oxford University Press 1961; $2^{\text {nd }}$ ed. "With a Postscript", 1994) 200, 205: "Laws require interpretation if they are to be applied to concrete cases, and once the myths which obscure the nature of the judicial processes are dispelled by realistic study, it is patent... that the open texture of law leaves a vast field for a creative activity which some call legislative". See also Imer B. Flores, 'H. L. A. Hart's Moderate Indeterminacy Thesis Reconsidered: In Between Scylla and Charybdis' (2011) 5 Problema. Anuario de Filosofía y Teoría del Derecho 147, 170 (criticizing Hart's indeterminacy thesis and defending Dworkin's determinacy thesis, by introducing a distinction between "interpretive" and "inventive" or "legislative" "creative judicial activity").

20 Dworkin, Law's Empire (n 10) 52. See Dworkin (n 9) 1252: “[Constructive interpretation] does not mean peeking inside the skulls of people dead for centuries. It means trying to make the sense we can of an historical event -someone, or a social group with particular responsibilities, speaking or writing in a particular way on a particular occasion". See also Flores (n 15) 1173-1174 (emphasizing the constructive nature of Dworkin's model).

${ }^{21}$ See Imer B. Flores, ¿¿Es el derecho un modelo aplicativo?' ['Is Law an Applicative Model?'], in Juan Federico Arriola Cantero \& Víctor Rojas Amandi (eds) La Filosofía del Derecho Hoy [Philosophy of Law Today] (Porrúa 2010).

22 See Larry Solum, 'We Are All Originalists Now', in Larry Solum and Robert W. Bennett Constitutional Originalism. A Debate (Cornell University Press 2011) 3: 
Esta revista forma parte del acervo de la Biblioteca Jurídica Virtual del Instituto de Investigaciones Jurídicas de la UNAM

should do is (constitutional) interpretation, whereas what legislatures do or should do is (constitutional) construction, but also suggests that originalist judges, by doing (constitutional) interpretation, instead of (constitutional) construction, are the only ones that can remain faithful to the Constitution, whilst the others are unfaithful and even infidels pronouncing heresies, revisions, subversions and so on. ${ }^{23}$

Actually, as Fleming points out, there are "several competing conceptions of fidelity...", namely: (1) "as pursuing integrity with the moral reading of the Constitution" (Ronald Dworkin); (2) "as synthesis of constitutional moments" (Bruce Ackerman); (3) "as translation across generations" (Lawrence Lessig); (4) "as keeping faith with founders' vision" (Jack Rakove); and (5) "[as keeping faith] to abstract text and principle" (Jack Balkin). ${ }^{24}$

Nevertheless, Dworkin is absolutely right when he gives a word of caution: "If courts try to be faithful to the text of the Constitution, they will for that very reason be forced to decide between competing conceptions of political morality". ${ }^{25}$ His counsel is one of fidelity, honesty and responsibility, by displaying the true grounds of judgment instead of concealing them or even pretending that no judgment was made and so no need to take responsibility for it. Let me quote Dworkin at length: ${ }^{26}$

I not only concede but emphasize that constitutional opinion is sensitive to political conviction... Constitutional politics has been confused and corrupted by a pretense that judges... could use politically neutral strategies of constitutional interpretation. Judges who

"Many originalists believe that it is important to distinguish between two distinct aspects of constitutional practice: constitutional interpretation and constitutional construction" (emphasis in the original). See also Keith E. Whittington, Constitutional Construction. Divided Powers and Constitutional Meaning (Harvard University Press 1999); and Keith E. Whittington, Constitutional Interpretation: Textual Meaning, Original Intent, and Judicial Review (University Press of Kansas 1999).

23 See, for example, Bork, The Tempting of America (n 17).

24 Fleming (n 1) 11. See Fleming (n 6) 1337. See also Symposium: Fidelity in Constitutional Theory (1997) 65 Fordham L. Rev.

25 Dworkin, Taking Rights Seriously (n 10) 136; and see Dworkin (n 11).

26 Dworkin (n 8) 37 (emphasis in the original). 
Esta revista forma parte del acervo de la Biblioteca Jurídica Virtual del Instituto de Investigaciones Jurídicas de la UNAM

join in that pretense try to hide the inevitable influence of their own convictions even from themselves, and the result is a costly mendacity. The actual grounds of decision are hidden from both legitimate public inspection and valuable public debate. The moral reading offers different counsel. It explains why fidelity to the Constitution and to law demands that judges make contemporary judgments of political morality, and it therefore encourages an open display of the true grounds of judgment, in the hope that judges will construct franker arguments of principle that allow the public to join in the argument.

So of course the moral reading encourages lawyers and judges to read an abstract constitution in the light of what they take to be justice.

\section{FLEMING'S FIDELITY TO OUR IMPERFECT CONSTITUTION: MORAL READINGS V. ORIGINALISMS (AND LIVING CONSTITUTIONALISMS)}

In his article "Fidelity to Our Imperfect Constitution", Fleming pointed out - with the help of a rhetorical pun - that the topic for the "Fidelity in Constitutional Theory" Symposium raised two fundamental questions: fidelity to what? and what is fidelity? The short answer to the first - "fidelity to the Constitution" - pointed to a further question: what is the Constitution? Similarly, the short answer to the second - "being faithful to the Constitution in interpreting it"- posed another question: How should the Constitution be interpreted? Certainly, the two questions what is interpreted? and how it is or should be interpreted?, along with the question of who is to interpret?, are the basic interrogatives of constitutional interpretation. ${ }^{27}$

On this regard, I will like to make the importance of the third one explicit, since I am fully convinced -following Dworkin's leadthat in a (constitutional) democracy or democratic system, everyone - judges, legislators, lawyers, citizens and other public officials-

27 See Fleming (n 6) 1335. See also Walter F. Murphy, James E. Fleming, Sotirios A. Barber \& Stephen Macedo, American Constitutional Interpretation ( $5^{\text {th }}$ ed., Foundation Press 2013). 
Esta revista forma parte del acervo de la Biblioteca Jurídica Virtual del Instituto de Investigaciones Jurídicas de la UNAM

are to interpret the Constitution, rejecting an exclusive attribution to or monopoly of a person or group. ${ }^{28}$ In that sense, since there will be countless interpretations, the question evolves into at least two different questions: who is to interpret authoritatively?, ${ }^{29}$ as well as, who is to interpret correctly? ? $^{30}$

In spite of the "majoritarian premise" and the so-called "countermajoritarian difficulty", ${ }^{31}$ almost all of our contemporary democracies, including those in transition from authoritarian regimes, have entrusted the responsibility of authoritative interpretation to judges sitting in constitutional, higher, or supreme courts and tribunals, which Dworkin rightly conceives as "the forum of principle". ${ }^{32}$ Notwithstanding, he clarified that: "I do not mean, of course, that only judges should discuss matters of high political principle. Leg-

28 See Imer B. Flores, 'Law, Liberty and the Rule of Law (in a Constitutional Democracy), in Imer B. Flores \& Kenneth E. Himma (eds), Law, Liberty and the Rule of Law 77 (Springer 2013).

29 See Dworkin (n 8) 2: "But political morality is inherently uncertain and controversial, so any system of government that makes such principles part of its law must decide whose interpretation and understanding will be authoritative".

30 See Dworkin, Taking Rights Seriously (n 10) 279: "My argument suppose that there is often a single right answer to complex questions of law and political morality. The objection replies that there is sometimes no single right answer, but only answers.” Ronald Dworkin, 'No Right Answer?' in P. M. S. Hacker \& Joseph Raz (eds.), Law, Morality and Society: Essays in Honour of H. L. A. Hart (Oxford University Press 1977) 84: "For all practical purposes, there will always be a right answer in the seamless web of our law.” Ronald Dworkin, 'Objectivity and Truth: You'd Better Believe It' (1996) 25 Phil. \& Pub. Affairs 87, 136: "This "no right answer" thesis cannot be true by default in law any more than in ethics or aesthetics or morals". See also Flores (n 15) 181-185.

31 See Alexander M. Bickel, The Least Dangerous Branch of Government. The Supreme Court at the Bar of Politics (2 ${ }^{\text {nd }}$ ed., Yale University Press 1986) 16, 18.

32 See Ronald Dworkin, 'The Forum of Principle' (1981) 56 N. Y. U. L. Rev. 469, reprinted in Dworkin, A Matter of Principle (n 13) 33. See also Imer B. Flores, 'Assessing Democracy and Rule of Law: Access to Justice', in Aleksander Peczenik (ed), Proceedings of the 21 $1^{\text {st }}$ IVR World Congress, Lund (Sweden), 12-17 August, 2003, Part I: Justice (Steiner, 2004) 146 (responding to the counter-majoritarian objection). 
Esta revista forma parte del acervo de la Biblioteca Jurídica Virtual del Instituto de Investigaciones Jurídicas de la UNAM

IMER B. FLORES

islatures are guardians of principles too, and that includes constitutional principle". ${ }^{33}$

Dworkin was adamant in his insistence that it is imperative to reject the "majoritarian premise" and the "counter-majoritarian difficulty" that reinforces the "majoritarian conception" of democracy, which "means government by the largest number of the people. On this majoritarian view the democratic ideal lies in a match between political decision and will of the majority or plurality of opinion". And, instead to replace it with the "partnership conception" of democracy, which "means government by all the people, acting together as full and equal partners in a collective enterprise of selfgovernment". 34

Accordingly, it is also necessary to transcend the debate about who is or should be the absolute or final authoritative interpreter: the legislator or the judge ${ }^{35}$ Actually, both have a very important duty, either to legislate political rights (and constitutional norms that remain under-enforced) or adjudicate legal rights, in both cases

33 Dworkin (n 8) 31.

34 Ronald Dworkin, Sovereign Virtue. The Theory and Practice of Equality (Harvard University Press, 2000) 357-358. See Dworkin (n 8) 15-19; Ronald Dworkin, 'The Partnership Conception of Democracy' (1998) 86 Cal. L. Rev. 453; Ronald Dworkin, Is Democracy Possible Here? Principles for a New Political Debate (Princeton University Press 2006) 131-137; and Ronald Dworkin, Justice for Hedgehogs (Harvard University Press 2011) 382-385. See also John Stuart Mill, Considerations on Representative Government (The Liberal Art Press 1958) 102103; and Imer B. Flores, ‘Ronald Dworkin's Justice for Hedgehogs and Partnership Conception of Democracy (With a Comment to Jeremy Waldron's "A Majority in the Lifeboat")' (2010) 4 Problema. Anuario de Filosofía y Teoría del Derecho 65, 73-76, 79-81.

35 See Bishop Benjamin Hoadly (sermon before the English King in 1717) quoted by John Chipman Grey, 'A Realist Conception of Law', in Joel Feinberg and Hyman Gross (eds), Philosophy of Law ( $3^{\text {rd }}$ ed., Wadsworth, 1986) 50: "Whoever hath an absolute authority to interpret any written or spoken laws, it is he who is truly the Law-giver to all intent and purposes, and not the person who first wrote or spoke them". See also Brown v. Allen, 344 U.S. 443, 540 (1953) (Jackson, J. concurring opinion): "We are not final because we are infallible, but we are infallible only because we are final". 
Esta revista forma parte del acervo de la Biblioteca Jurídica Virtual del Instituto de Investigaciones Jurídicas de la UNAM

according to the Constitution and the law. ${ }^{36}$ In a democracy, everyone has and must have its share: it implies a division of labor. ${ }^{37}$

Additionally, it is not a matter of who is or should be the absolute or final authoritative interpreter, but of who is or should be to interpret correctly? Let me suggest that this last question conflates with the question: how it is or should be interpreted? Or, alternately: which is the best or better interpretation? In other words: is there a right answer or not? Originalists assume that their interpretation is the best or better one - and even the only one- because they are in the grip of what Fleming calls the "originalist premise", i. e. "the assumption that originalism, rightly conceived, is the best, or indeed the only, conception of fidelity in constitutional interpretation. Put more strongly, it is the assumption that originalism, rightly conceived, has to be the best - or indeed the only- conception of constitutional interpretation" ${ }^{38}$

Clearly, Fleming reacts to the "originalist premise" and rejects all forms of originalisms, regardless of whether they are concerned with the original meaning or public meaning of the text, the original intention or understanding of the drafters, framers or ratifiers, the original applications or expectations, original methods or the like, and reconnoiters all the variants, including old or new, strong or weak, exclusive or inclusive, living or dead, broad or narrow, abstract or concrete. ${ }^{39}$

36 See Dworkin, Justice for Hedgehogs (n 34) 405-407, 412-413. See also Lawrence G. Sager, 'Fair Measure: The Legal Status of Underenforced Constitutional Norms' (1978) 91 Harv. L. Rev. 1212; and Lawrence G. Sager, 'Justice in Plain Clothes: Reflections on the Thinness of Constitutional Law' (1993) 88 Nw. U. L. Rev. 410.

37 See Imer B. Flores, 'The Quest for Legisprudence: Constitutionalism v. Legalism', in Luc J. Wintgens (ed), The Theory and Practice of Legislation: Essays on Legisprudence (Ashgate 2005) 26-52; Imer B. Flores, 'Legisprudence: The Forms and Limits of Legislation' (2007) 1 Problema. Anuario de Filosofía y Teoría del Derecho 247; Imer B. Flores, 'Legisprudence: The Role and Rationality of Legislators — visà-vis Judges - towards the Realization of Justice' (2009) 1:2 Mexican Law Review. New Series 91; and Imer B. Flores, 'The Living Tree Constitutionalism: Fixity and Flexibility’ (2009) 3 Problema. Anuario de Filosofía y Teoría del Derecho 37 (2009).

38 Fleming (n 1) 7. See Fleming (n 6) 1344.

39 See Fleming (n 6) 1344. See also Fleming (n 1) 2-3. 
Esta revista forma parte del acervo de la Biblioteca Jurídica Virtual del Instituto de Investigaciones Jurídicas de la UNAM

IMER B. FLORES

A clarification is in order: Fleming appears to be sympathetic with some forms of originalism, i. e. inclusive, living, broad and abstract, as long as they can be reformulated as or compatible with moral readings, and as such can be welcomed into the big tent of moral readings. We will return to this point in the last part of this Article. Nevertheless, the structure of the book is quite simple and very straightforward.

In Chapter 1, "Are We All Originalists Now? I Hope Not!", which serves as introduction to the book, Fleming expands his homonymous article ${ }^{40}$ to update his responses to this question, and to those like Lawrence Solum, who answer it affirmatively "We are All Originalists Now", ${ }^{41}$ and to those, like William Baude, who - following Elena Kagan's apparent concession, at her confirmation hearing, that "we are all originalists" - reframes the question as "Is Originalism our Law?" to answer: "Yes, at least in a presumptive sense, its deep structure is a nuance form of originalism". ${ }^{42}$ In this chapter Fleming also incorporates the core of another article "The Balkinization of Originalism", ${ }^{43}$ in which he points out the main problem of the all-inclusive tent of and for originalists, with another brilliant pun: "the Balkanization of originalism and the Balkinization of originalism". In short, he suggests: "we are witnessing the 'Balkanization' of originalism (when originalism splits into warring camps) and the 'Balkinization' of originalism (when even Balkin, hitherto a pragmatist living constitutionalist, becomes an originalist)". ${ }^{4}$

${ }^{40}$ James E. Fleming, 'Are We All Originalists Now? I Hope Not!' (2013) 91 Texas L. Rev. 1785.

41 See Solum (n 22) 1. See also Randy W. Barnett, 'Underlying Principles' (2007) 24 Const. Comment. 405 (reviewing Jack M. Balkin, 'Abortion and Original Meaning' (2007) 24 Const. Comment. 291).

42 See William Baude, 'Is Originalism our Law?' (2015) 115 Columbia L. Rev. 2349.

43 James E. Fleming, 'The Balkinization of Originalism' (2012) 3 U. Illinois L. Rev. 669.

44 Fleming (n 1) 2; James E. Fleming, 'The Balkanization of Originalism' (2007) 67 Maryland L. Rev. 10; and Fleming (n 43) 670. See, for instance, Mitchel N. Berman, 'Originalism Is Bunk' (2009) 84 N. Y.U. L. Rev. 1 (distinguishing seventy-two varieties of originalism). See also Jack Balkin, Living Originalism (Harvard University Press 2011) (willing to occupy the intermediate position between originalism and living constitutionalism, by renaming his position "living originalism"). 
Esta revista forma parte del acervo de la Biblioteca Jurídica Virtual del Instituto de Investigaciones Jurídicas de la UNAM

In Part One, "The New Originalism and Its Originalist Discontent", Fleming challenges the new originalism and examines its originalist discontent. Along these lines, in Chapter 2, "The New Originalist Manifesto", ${ }^{45}$ he exposes and criticizes the "new originalist manifiesto", as redefined or refined elegantly by Solum around four basic ideas: 1) The fixation thesis; 2) The public meaning thesis; 3) The textual constraint thesis; and 4) The interpretation-construction distinction. Fleming is absolutely right that these ideas represent a problem for originalists, especially the fourth, which gives room for a "construction zone" that lies beyond originalism and requires, by definition, normative judgments, and, as such, is considered as a capitulation in favor - for different reasons - of both living constitutionalisms and moral readings, and contributes to generate discontent among old and even contemporary originalists. ${ }^{46}$

Similarly, in Chapter 3, "Fidelity, Change, and the Good Constitution", ${ }^{47}$ he corroborates that the new originalism has provoked a pushback within originalism, with the appearance of the "original methods originalism" and the reappearance of the "oldtime originalism", and demonstrates that the reasons for aspiration to fidelity correspond to the moral reading or philosophical approach that conceives fidelity as honoring our commitments to "abstract aspirational principles", not concrete or specific ones. As Dworkin puts it: "We have to choose between an abstract, principled, moral reading... and a concrete, dated, reading".48

In Part Two, "A Moral Reading or Philosophical Approach", Fleming defines and defends his moral reading or philosophical approach as an alternative to originalism. In Chapter 4, "Fidelity through a Moral Reading or Philosophical Approach", he develops his substantive and interpretative theory, and responds to objections to it; and, in Chapter 5, "The Place of Precedent and Common-Law Constitu-

45 See James E. Fleming, The New Originalist Manifiesto (2013) 28 Const. Comment. 539.

46 Fleming (n 1) 28-29.

47 James E. Fleming, 'Fidelity, Change, and the Good Constitution' (2014) 62 The Am. J. of Comp. L. 515.

48 Dworkin (n 9) 1253. 
Esta revista forma parte del acervo de la Biblioteca Jurídica Virtual del Instituto de Investigaciones Jurídicas de la UNAM

tional Interpretation", he reiterates a conclusion present ever since the publication of "Fidelity to Our Imperfect Constitution", namely that "History is, can only be, and should only be a starting point in constitutional interpretation". ${ }^{4}$

Let me also call your attention to a passage of Antonin Scalia's Tanner Lecture, "Common-Law Courts in a Civil-Law System: The Role of United States Federal Courts in Interpreting the Constitution and Laws": 50

[T] he common law grew in a peculiar fashion - rather like a Scrabble board. No rule of decision previously announced could be erased, but qualifications could be added to it. The first case lays on the board: "No liability for breach of contractual duty without privity"; the next player adds "unless injured party is member of household". And the game continues.

As you can imagine, I am fully convinced that since history cannot be erased, but added, Fleming is certainly right: History is, can only be, and should only be a starting point in constitutional interpretation... and not the ending point or finishing line. Recall Oliver Wendell Holmes' celebrated article, "The Path of Law", where he, on the one hand, admitted:

At present, in very many cases, if we want to know why a rule of law has taken its particular shape, and more or less if we want to know why it exists at all we go to tradition... The rational study of law is still to a large extent the study of history. History must be a part of the study.

On the other hand, he warned: "Everywhere the basis of principle is tradition, to such an extent that we even are in danger of making the rôle of history more important than it is". ${ }^{51}$

49 Fleming (n 6) 1350.

50 Antonin Scalia, 'Common-Law Courts in a Civil-Law System: The Role of United States Federal Courts in Interpreting the Constitution and Laws', in Amy Gutmann (ed), A Matter of Interpretation. Federal Courts and the Law (Princeton University Press 1997) 8.

51 Oliver Wendell Holmes, 'The Path of the Law' (1997) 110 Harvard L. Rev. 991, 1003 (published originally: 1897). See Imer B. Flores, 'The Problem about the Nature of Law vis-à-vis Legal Rationality Revisited: Towards an Integrative Jurisprudence', in Wil Waluchow \& Stefan Sciaraffa (eds), The Philosophical Foundations of the Nature of Law (Oxford University Press 2013) 101. 
Esta revista forma parte del acervo de la Biblioteca Jurídica Virtual del Instituto de Investigaciones Jurídicas de la UNAM

In Part Three, "Living Originalism and Living Constitutionalism as Moral Readings", Fleming recasts, or at least tries to recast, some theories as moral readings and theorists as moral readers: in Chapter 6, "Fidelity through Living Originalism: Redeeming the Promises of the Constitution" - Jack Balkin's living originalism - and in Chapter 7, "Fidelity to Our Living Constitution: Honoring the Achievements of We the People" - Bruce Ackerman's living constitutionalism. The problem for Fleming is that both authors, despite assuming the existence of abstract principles, have long resisted the moral reading and its implications in favor of pragmatic considerations. ${ }^{52}$

In Part Four, "Fidelity to Our Imperfect Constitution", Fleming reconsiders the pragmatic argument that it is time to rewrite the United States Constitution based on the argument that it is imperfect. On the contrary, he argues that the better approach is to maintain an attitude of fidelity to our imperfect Constitution, and to apply a constitutional-perfecting theory that interprets the Constitution so as to make it the best it can be.

Finally, in "Epilogue: Accepting our Responsibility", Fleming concludes with a call to accept responsibility for making normative judgments and welcoming those who are willing to accept it into the moral reading tent:

Moral readers accept our responsibility not to retreat from interpreting the Constitution so as to fulfill the promise of our commitments to abstract aspirational principles such as liberty and equality - not to retreat to originalism. We appreciate that the aspiration to

52 I confess to at one time also thinking that Ackerman's living constitutionalisms and Balkin's synthetizing originalism and living constitutionalism project, i. e. living originalism, were compatibles with a Dworkinian moral reading approach. Since, I have come to conclude that they are not, as we will see in the IV Part of this Article. But I still think that the "living tree constitutionalism" is a moral reading. See Flores, 'The Living Tree Constitutionalism', supra note 37, at 41, 74 (commenting on Wilfrid J. Waluchow, A Common Law Theory of Judicial Review: The Living Tree (Cambridge University Press 2007)). By the by, the "living tree" metaphor, suggesting both fixity and flexibility, can be traced all the way back to John Stuart Mill, On Liberty 56-57 (Hackett, 1978; originally published: 1859): "Human nature is not a machine to be built after a model, and set to do exactly the work prescribed for it, but a tree, which requires to grow and develop itself on all sides, according to the tendency of the inward forces which make it a living thing". 
Esta revista forma parte del acervo de la Biblioteca Jurídica Virtual del Instituto de Investigaciones Jurídicas de la UNAM

fidelity requires citizens, scholars, and judges not to avoid or evade the responsibility to make normative judgments about the best understanding of those commitments.

\section{CONSTITUTIONAL FIDELITY, INTERPRETATION,}

AND IMPERFECTION: INTELLIGENT OR UNINTELLIGENT?

Let me explicit that Fleming's apt title for his article and book, i. e. "Fidelity to Our Imperfect Constitution", has implicit in it three very helpful dichotomies to distinguish the different theories: (1) fidelity and anti-fidelity; (2) interpretation and non-interpretation aka (re) construction, (re)invention and (judicial) legislation; and 3) perfection-imperfection.

Accordingly, "originalists" assume that they are the only ones that can have fidelity to the Constitution as written, by limiting themselves to the interpretation of the Constitution, which somehow is and remains a symbol of perfection. On the contrary, "living constitutionalists" assume an anti-fidelity position suggesting that it is time to rewrite the Constitution, by a pragmatic process of non-interpretation through (re)construction, (re)invention and (judicial) legislation, due to its imperfection. Finally, "moral readers" (like Fleming and myself) assume that they (we) also have fidelity to the Constitution as written, to the extent that the best or better approach is to continue with its interpretation, recognizing that it is not a symbol of perfection, but of imperfection, and as such perfectible as any human endeavor.

By now, it is clear that the kind of interpretation that moral readers and originalists have in mind is very different: a constructive interpretation for moral readers, on one side, and a mere applicative interpretation for originalists, on the other. However, the kind of fidelity in question is still not that evident.

So, the remaining or underlying question is what kind of fidelity? My response, following Lon L. Fuller's distinction between intelligent and unintelligent fidelity, is unsurprising: intelligent fidelity. The distinction can be traced to a passage of his not so hypothetical "The Case of the Speluncean Explorers", in voice of Foster, J.: 
Esta revista forma parte del acervo de la Biblioteca Jurídica Virtual del Instituto de Investigaciones Jurídicas de la UNAM

There are those who raise the cry of judicial usurpation whenever a court, after analyzing the purpose of a statute, gives its words a meaning that is not at once apparent to the causal reader who has not studied the statute closely or examined the objectives it seeks to attain. Let me say emphatically that I accept without reservation the proposition that this Court is bound by the statutes of our Commonwealth and that it exercises its powers in subservience to the duly expressed will of the Chamber of Representatives. The line of reasoning I have applied above raises no question of fidelity to enacted law, though it may possibly raise a question of the distinction between intelligent and unintelligent fidelity. No superior wants a servant who lacks the capacity to read between the lines. The stupidest housemaid knows the when she is told "to peel the soup and skin the potatoes" her mistress does not mean what she says. She also knows that when her master tells her to "drop everything and come running" he has overlooked the possibility that she is at the moment in the act of rescuing the baby from the rain barrel. Surely we have a right to expect the same modicum of intelligence from the judiciary. The correction of obvious legislative errors or oversights is not to supplant the legislative will, but to make that will effective..$^{53}$

It is clear that one thing is fidelity to law as enacted or written and another is fidelity to law itself. Actually, as Fuller points out, also in voice of Foster, J.:

Now it is, of course, perfectly clear that these men did an act that violates the literal wording of the statute which declares that he who "shall willfully take the life of another" is a murderer. But one of the most ancient bits of legal wisdom is the saying that a man may break the letter of the law without breaking the law itself. Every proposition of positive law, whether contained in a statute or a judicial precedent, is to be interpreted reasonably, in the light of its evident purpose. $^{54}$

Furthermore, as it is well accredited, Fuller returned to the issue of fidelity to law in a rejoinder, entitled "Positivism and Fidelity to

53 Lon L. Fuller, 'The Case of the Speluncean Explorers' (1948-1949) 62 Harv. L. Rev. 616, 625-626 (reprinted in (1999) 112 Harv. L. Rev. 1851) (the emphasis is mine).

54 Ibidem, 620. 
Esta revista forma parte del acervo de la Biblioteca Jurídica Virtual del Instituto de Investigaciones Jurídicas de la UNAM

Law -A Reply to Professor Hart", 55 sparked by H. L. A. Hart's Oliver Wendell Holmes Lecture, at Harvard Law School, in April 1957, titled "Positivism and the Separation of Law and Morals", which was published in Harvard Law Review the following year. ${ }^{56}$ However, what is not as credited is that at the time Ronald Dworkin "was one of the self-appointed 'gods' editing the Law Review" ${ }^{57}$

Let me recall that Fuller starts his reply by acknowledging the cardinal virtues of the article, among them and chiefly: "Now, with Professor Hart's paper, the discussion takes a new and promising turn. It is now explicitly acknowledged on both sides that one of the chief issues is how we can best define and serve the ideal of fidelity to law". ${ }^{58}$ Immediately after he adds:

Law, as something deserving loyalty, must represent a human achievement; it cannot be a simple fiat of power or a repetitive pattern discernible in the behavior of state officials. The respect we owe to human laws must surely be something different from the respect we accord to the law of gravitation. If laws, even bad laws, have a claim to our respect, then law must represent some general direction of human effort that we can understand and describe, and that we can approve in principle even at the moment when it seems to us to miss its mark. ${ }^{59}$

What's more, in the part addressing the problem of interpretation, Fuller comes with an illustration to test not only Hart's theory of the core and penumbra, but also its relevance to the ideal of fidelity to law as well:

Let us suppose that in leafing through the statutes, we come upon the following enactment: "It shall be a misdemeanor, punishable by a fine of five dollars, to sleep in any railway station". We have no trouble in perceiving the general nature of the target toward which

55 Lon L. Fuller, 'Positivism and Fidelity to Law -A Reply to Professor Hart' (1958) 71 Harv. L. Rev. 630.

56 H. L. A. Hart, 'Positivism and the Separation of Law and Morals' (1958) 71 Harv. L. Rev. 593.

57 Nicola Lacey, A Life of H. L. A. Hart. The Nightmare and the Noble Dream (Oxford University Press 2004) 185.

58 Fuller (n 55) 632.

59 Idem. 
Esta revista forma parte del acervo de la Biblioteca Jurídica Virtual del Instituto de Investigaciones Jurídicas de la UNAM

this statute is aimed. Indeed, we are likely at once to call to mind the picture of a disheveled tramp, spread out in an ungainly fashion on one of the benches of the station, keeping weary passengers on their feet and filling their ears with raucous and alcoholic snores. This vision may fairly be said to represent the "obvious instance" contemplated by the statute, though certainly is far from being the "standard instance" of the physiological state called "sleep".

Now let us see how this example bears on the ideal of fidelity to law. Suppose I am a judge, and that two men are brought before me for violating this statute. The first is a passenger who was waiting at 3 A.M. for a delayed train. When he was arrested he was sitting upright in an orderly fashion, but was heard by the arresting officer to be gently snoring. The second is a man who had brought a blanket and pillow to the station and had obviously settled himself down for the night. He was arrested, however, before he had a chance to go to sleep. Which of these cases presents the "standard instance" of the word "sleep"? If I disregard that question, and decide to fine the second man and set free the first, have I violated a duty of fidelity to law? Have I violated that duty if I interpret the word "sleep" as used in this statute to mean something like "to spread oneself out on a bench or floor to spend the night, or as if to spend the night"?

Although the first man felt asleep and the second one did not have a chance to go to sleep, it is clear to me that it will be an unintelligent fidelity to law, if the judge decides to fine the first for falling sleep and breaking the letter of the law; and let go the second for not having the chance to go to sleep and not breaking the letter of the law yet, while he was willing to break not only the letter of the law but also the law itself. Additionally, it is clear that it will be an unintelligent fidelity to law, if the judge decides to fine both or to let go both, as one broke the letter of the law and the other broke the law itself or at least was willing to do it, since the judge will be failing to follow the principle of "treating like cases alike and unlike cases differently".

On the contrary, it will be an intelligent fidelity, if the judge decides to let go the first, despite the fact that he had fallen sleep, although he had no intention to spend the night (or part of it), as he broke the letter of the law, but not the law itself; and to fine the second, in spite of the fact that he had no chance to go to sleep, although he had the 
Esta revista forma parte del acervo de la Biblioteca Jurídica Virtual del Instituto de Investigaciones Jurídicas de la UNAM

intention to spend the night (or part of it), because he broke the law itself, but not the letter of the law.

Finally, the relevance of the distinction between intelligent and unintelligent fidelity, for the debate between moral readings and originalist approaches, is captured in the following quotation: "The moral reading insists that they [i. e. the drafters and the ratifiers] misunderstood the moral principle that they themselves enacted into law. The originalist strategy would translate that mistake into enduring constitutional law". 60

To illustrate the point, keep in mind that the Supreme Court of the United States of America in Plessy v. Ferguson (1896), with an unintelligent fidelity following an originalist strategy, translated a mistake into enduring constitutional law, by justifying the "separated, but equal doctrine". And so, in Brown v. Board of Education (1954), the Supreme Court with an intelligent fidelity, following a moral reading, did correct such mistake, by understanding the moral principle enacted into law with the Fourteenth Amendment, drafted in 1866 and ratified in 1868, i. e. equal protection of the law. ${ }^{61}$

\section{CONCLUSION}

To conclude, let me recall that I concurred with Fleming, in his response to the question: Are we all originalists now? "I hope not", and to his rhetorical question: Are we all moral readers now? I answer, "I

60 Dworkin (n 8) 13.

61 For the living constitutionalism or pragmatic approach, see Alexander M. Bickel, 'The Original Understanding and the Segregation Decision' (1955) 69 Harv. L. Rev. 1, 1 (quoting Chief Justice Warren's unanimous opinion in Brown v. Board of Education, 347 U.S. 483 (1954), 492-493: "In approaching this problem, we cannot turn the clock back to 1868 when the Amendment was adopted, or even to 1896 when Plessy v. Ferguson was written. We must consider public education in the light of its full development and its present place in American life throughout the Nation. Only in this way can it be determined if segregation in public schools deprives these plaintiffs of the equal protection of the laws"; and, 65 (commenting "The Court... was able to avoid the dilemma because the record of history, properly understood, left the way open to, in fact invited, a decision based on the moral and material state of the nation in 1954, not 1866"). 
Esta revista forma parte del acervo de la Biblioteca Jurídica Virtual del Instituto de Investigaciones Jurídicas de la UNAM

believe not and hope not". Somehow my idea was that not everyone is willing to admit that they are making moral readings, i. e. normative judgments, and much less willing to accept their responsibility for doing so. Once they admit and accept it, as Fleming asks, we all will be moral readers, welcomed in a big tent to sing along.

\section{BIBLIOGRAPHY}

Ackerman B, 'The Living Constitution' (2007) 120 HL. Rev. 1737.

Balkin J, Living Originalism (Harvard University Press 2011).

Barber SA \& Fleming JE, Constitutional Interpretation. The Basic Questions (Oxford University Press 2007).

Barber SA, Fleming JE, Murphy WF \& Macedo S, American Constitutional Interpretation ( $5^{\text {th }}$ ed., Foundation Press 2013).

Barnett RW, 'Underlying Principles' (2007) 24 Const. Comment 405.

Baude W, 'Is Originalism our Law?' (2015) 115 Columbia L. Rev 2349.

Beard CA, 'The Living Constitution' (1936) 185 Annals of the American Association of Political Sciences 29.

Berger R, Government by the Judiciary. The Transformation of the Fourteenth Amendment (Harvard University Press 1977).

Berman MN, 'Originalism Is Bunk' (2009) 84 NYUL Rev. 1.

Bickel AM, 'The Original Understanding and the Segregation Decision' (1955) 69 Harv. L. Rev. 1, 1.

, The Least Dangerous Branch of Government. The Supreme Court at the Bar of Politics $\left(2^{\text {nd }}\right.$ ed., Yale University Press 1986) 16, 18.

Bork RH, 'Neutral Principles and some First Amendment Problems' (1971) 47 Indiana L. J. 1.

-, The Tempting of America. The Political Seduction of the Law (The Free Press 1990).

Chipman Grey J, 'A Realist Conception of Law', in Joel Feinberg and Hyman Gross (eds), Philosophy of Law ( $3^{\text {rd }}$ ed., Wadsworth, 1986). 
Esta revista forma parte del acervo de la Biblioteca Jurídica Virtual del Instituto de Investigaciones Jurídicas de la UNAM

Dworkin R, 'A Special Supplement: The Jurisprudence of Richard Nixon' (1972), N. Y. Rev. Books (May 4) <http://www.nybooks.com/articles/1972/05/04/a-special-supplementthe-jurisprudence-of-richard-/> accesed 16 september 2016.

, 'Objectivity and Truth: You'd Better Believe It' (1996) 25 Phil. \& Pub. Affairs 87.

, 'The Arduous Virtue of Fidelity: Originalism, Scalia, Tribe, and Nerve' (1997) 65 Fordham L. Rev. 1249.

, 'The Forum of Principle' (1981) 56 N. Y. U. L. Rev. 469.

, 'The Partnership Conception of Democracy' (1998) 86 Cal. L. Rev. 453.

A Matter of Principle (Harvard University Press 1985) 158162.

, Freedom's Law. The Moral Reading of the American Constitution (Harvard University Press 1996).

, Is Democracy Possible Here? Principles for a New Political Debate (Princeton University Press 2006) . , Justice for Hedgehogs (Harvard University Press 2011).

, Justice in Robes (Harvard University Press 2006).

- Law's Empire (Harvard University Press 1986).

- Sovereign Virtue. The Theory and Practice of Equality (Harvard University Press, 2000).

, Taking Rights Seriously (Harvard University Press 1977; $2^{\text {nd }}$ ed. "With a Reply to Critics", 1978) 131, 149.

Fleming JE \& McClain LC, Ordered Liberty. Rights, Responsibilities, and Virtues (Harvard University Press 2013).

,Are We All Originalists Now? I Hope Not!' (2013) 91 Texas L. Rev. 1785.

, 'Fidelity to Our Imperfect Constitution', (1997) 65 Fordham L. Rev. 1335.

, 'Fidelity, Change, and the Good Constitution' (2014) 62 The Am. J. of Comp. L 515. 
Esta revista forma parte del acervo de la Biblioteca Jurídica Virtual del Instituto de Investigaciones Jurídicas de la UNAM

CONSTITUTIONAL INTERPRETATION, INTELLIGENT FIDELITY, AND (IM) PERFECTION:...

, 'Fit, Justification, and Fidelity in Constitutional Interpretation' (2013) 93 Boston U. L. Rev. 1283.

, 'The Balkinization of Originalism' (2012) 3 U. Illinois L. Rev. 669.

- Fidelity to Our Imperfect Constitution. For Moral Readings and Against Originalisms (Oxford University Press 2015).

, Securing Constitutional Democracy. The Case of Autonomy (The University of Chicago Press 2006).

, Symposium: Fidelity in Constitutional Theory (1997) 65 Fordham L. Rev.

, The New Originalist Manifiesto (2013) 28 Const. Comment. 539.

Flores IB, ‘¿Es el derecho un modelo aplicativo?' ['Is Law an Applicative Model?'], in Juan Federico Arriola Cantero \& Víctor Rojas Amandi (eds) La Filosofía del Derecho Hoy [Philosophy of Law Today] (Porrúa 2010).

, 'Assessing Democracy and Rule of Law: Access to Justice', in Aleksander Peczenik (ed), Proceedings of the $21^{\text {st }}$ IVR World Congress, Lund (Sweden), 12-17 August, 2003, Part I: Justice (Steiner, 2004) 146.

, 'H.L.A. Hart's Moderate Indeterminacy Thesis Reconsidered: In Between Scylla and Charybdis' (2011) 5 Problema. Anuario de Filosofía y Teoría del Derecho 147.

, 'Law, Liberty and the Rule of Law (in a Constitutional Democracy), in Imer B. Flores IB \& Himma KE (eds), Law, Liberty and the Rule of Law 77 (Springer 2013).

, 'Legisprudence: The Forms and Limits of Legislation' (2007)

1 Problema. Anuario de Filosofía y Teoría del Derecho 247.

, 'Legisprudence: The Role and Rationality of Legislators - vis-

à-vis Judges - towards the Realization of Justice' (2009) 1:2 Mexican Law Review. New Series 91.

, 'Ronald Dworkin's Justice for Hedgehogs and Partnership Conception of Democracy (With a Comment to Jeremy Waldron's “A Majority in the Lifeboat")' (2010) 4 Problema. Anuario de Filosofía y Teoría del Derecho 65. 
Esta revista forma parte del acervo de la Biblioteca Jurídica Virtual del Instituto de Investigaciones Jurídicas de la UNAM

-, 'The Legacy of Ronald Dworkin (1931-2013): A Legal Theory and Methodology for Hedgehogs, Hercules, and One Right Answers' (2015) 9 Problema. Anuario de Filosofía y Teoría del Derecho.

, 'The Living Tree Constitutionalism: Fixity and Flexibility' (2009) 3 Problema. Anuario de Filosofía y Teoría del Derecho 37.

, 'The Problem about the Nature of Law vis-à-vis Legal Rationality Revisited: Towards an Integrative Jurisprudence', in Wil Waluchow \& Stefan Sciaraffa (eds), The Philosophical Foundations of the Nature of Law (Oxford University Press 2013) 101.

, 'The Quest for Legisprudence: Constitutionalism v. Legalism', in Luc J. Wintgens (ed), The Theory and Practice of Legislation: Essays on Legisprudence (Ashgate 2005) 26,52.

Fuller LL, 'Positivism and Fidelity to Law --A Reply to Professor Hart' (1958) 71 Harv. L. Rev. 630.

, 'The Case of the Speluncean Explorers' (1948-1949) 62 Harv. L. Rev. 616, 625-626 (reprinted in (1999) 112 Harv. L. Rev. 1851).

Hacker PMS \& Raz J (eds), Law, Morality and Society: Essays in Honour of H.L.A. Hart (Oxford University Press 1977).

Hart HLA, 'Positivism and the Separation of Law and Morals' (1958) 71 Harv. L. Rev. 593.

- The Concept of Law (Oxford University Press 1961; $2^{\text {nd }}$ ed. "With a Postscript", 1994).

Hart J, Democracy and Distrust. A Theory of Judicial Review (Harvard University Press 1980).

Holmes OW, 'The Path of the Law' (1997) 110 Harvard L. Rev. 991, 1003 (published originally: 1897).

Lacey N, A Life of H.L.A. Hart. The Nightmare and the Noble Dream (Oxford University Press 2004) 185.

Mill JS, Considerations on Representative Government (The Liberal Art Press 1958). 
Esta revista forma parte del acervo de la Biblioteca Jurídica Virtual del Instituto de Investigaciones Jurídicas de la UNAM

CONSTITUTIONAL INTERPRETATION, INTELLIGENT FIDELITY, AND (IM) PERFECTION:...

- On Liberty 56-57 (Hackett, 1978; originally published: 1859).

Rehnquist WH, 'The Notion of a Living Constitution' (1976) 54 Texas

L. Rev. 693, reprinted in (2005-2006) 29 Harv. J. L. \& Pub. Pol'y 395.

Sager LG, 'Fair Measure: The Legal Status of Underenforced Constitutional Norms' (1978) 91 Harv. L. Rev. 1212.

'Justice in Plain Clothes: Reflections on the Thinness of Constitutional Law' (1993) 88 Nw. U. L. Rev. 410.

Scalia A, 'Common-Law Courts in a Civil-Law System: The Role of United States Federal Courts in Interpreting the Constitution and Laws', in Amy Gutmann (ed), A Matter of Interpretation. Federal Courts and the Law (Princeton University Press 1997).

, 'Originalism: The Lesser Evil’ (1989) 57 U. Cin. L. Rev. 849.

Solum L, 'We Are All Originalists Now', in Larry Solum and Robert W. Bennett Constitutional Originalism. A Debate (Cornell University Press 2011).

Strauss DA, The Living Constitution (Oxford University Press 2010).

Whittington KE, Constitutional Construction. Divided Powers and Constitutional Meaning (Harvard University Press 1999).

- Constitutional Interpretation: Textual Meaning, Original Intent, and Judicial Review (University Press of Kansas 1999).

\section{Cases}

Brown v. Allen, 344 U.S. 443, 540 (1953)

Southern Pacific v. Jensen, 244 U.S. 205, 221-222 (1917) 